\title{
FAMILY LAW: COURT DETERMINES GHILD GONGEIVED BY ARTIFICIAL INSEMINATION TO BE ILLEGITIMATE
}

\begin{abstract}
Althougr the gap between socio-scientific developments and the law may not be altogether undesirable, ${ }^{1}$ the recent case of Gursky $v$. Gursky is a graphic illustration of the bizarre result which may be reached by the application of traditional legal concepts to modern developments in medicine and sociology. In Gursky a New York supreme court applied the words "out of wedlock" in a narrow sense and concluded that a child conceived by artificial insemination with the semen of a third party donor (A.I.D.) ${ }^{3}$ is illegitimate, regardless of the written consent of the mother's husband. ${ }^{4}$ The question whether a child conceived by this means is illegitimate is not merely academic since every year a large number of births result from this process. ${ }^{5}$

In Gursky, despite the birth of a child to the defendant wife, evidence that the marriage had never been consummated was admitted to establish grounds for annulment. Plaintiff husband and defendant wife had agreed to artificial insemination of the latter with the semen of a third party donor, and the husband had been named as the father on the birth certificate of the resultant child. ${ }^{6}$
\end{abstract}

1 "The lag between medicine and law is not only inevitable but desirable. Too often scientific theories and practices fail to fulfil their promise. Were medical discoveries immediately reflected in the law, we would have not progress but chaos. Science with impunity may reverse itself repeatedly; the law, hardly ever." Tucker, Legal Problems of Artificial Insemination, 33 WOMEN LAw. J. 57, 58 (1947).

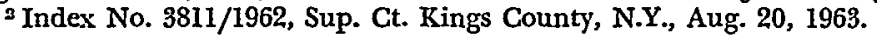

${ }^{8}$ There are three techniques employed in the practice of artificial insemination. A.I.D. is heterologous artificial insemination. This technique employs the semen of a third party donor. A.I.H. is homologous artificial insemination which employs only the semen of the husband. This practice is generally used where the husband is impotent but not sterile. The process of mixing the sperm of the husband with that of a third party donor is known as A.I.C. Hager, Artificial Insemination: Some Practical Considerations for Effective Counseling, 39 N.C.L. REv. 217, 222-23 (1961).

t Gursky v. Gursky, Index No. 3811/1962, Sup. Ct. Kings County, N.Y., Aug. 20, 1963.

"Some authorities estimated that by 1957 there were as many as one hundred thousand "test tube" babies in the United States. Gittinger, Artificial Insemination: Its Place in Washington Law, 32 Wash. L. REv. 280 n.1 (1957).

Another authority states: "It is impossible to determine how many babies are born annually in the United States as the result of donor insemination, but I would estimate between five and seven thousand." Guttmacher, The Role of Artificial Insemination in the Treatment of Sterility, 15 OBSTETRICAL, \& GYNECOLOGICAL SURVEX 767, 769 (1960).

' Gursky v. Gursky, Index No. 3811/1962, Sup. Ct. Kings County, N.Y., Aug. 20, 1963. 
Although it does not appear from the report of the case for what reason the court considered the question of legitimacy, this issue received the greater part of the court's attention. The basis for declaring the A.I.D. child illegitimate was found in the historical concept that a child begotten by a father not the mother's husband is illegitimate. ${ }^{7}$ The court concluded that this concept was the essence of the phrase "born out of lawful matrimony" as those words are used in a New York statute defining legitimacy. ${ }^{8}$

This intrusion of a third party donor into the marriage relationship has given rise to much legal uncertainty. ${ }^{\circ}$ If the A.I.D. child is declared illegitimate, he may find that since the laws regarding intestate succession are generally based on blood relationship, ${ }^{10}$ he is not entitled to inherit from his mother's husband. Furthermore, if a testator leaves property to the husband's "child" or "issue" and these words are used in their technical sense, the child may be incapable of taking under the will. ${ }^{11}$ This reasoning might permit the A.I.D. child to inherit as the child or issue of the third party donor, ${ }^{12}$ but since the identity of the donor is seldom, if ever, known to the A.I.D. child or his mother, the value of such an allowance is dubious.

The question of support for the illegitimate A.I.D. child caused little difficulty in Gursky, where the court found the mother's husband liable for the child's support on the basis that the husband's consent to the impregnation constituted an implied promise to

\footnotetext{
Tlbid.

s"A child born out of wedlock is a child begotten and born: (a) Out of lawful matrimony; (b) while the husband of its mother was separated from her a whole year previous to its birth; or (c) during the separation of its mother from her husband pursuant to a judgment of a competent court." N.Y. DOM. REL. LAW $\$ 119$.

- There is a possibility that the practice of A.I.D. will result in criminal liability. A list of possible offenses might include bastardy, criminal conversation, and lewdness. In addition the doctor involved might give consideration as to whether an implied warranty of fitness will attach to the semen that he selects, and depending upon how the birth certificate is prepared, whether he might be liable for fraud and misreprcsentation. Gittinger, supra note 5 , at 283-90.

${ }^{10}$ The New York statute regarding intestate succession declares: "If there be no surviving spouse, and no children, and no representatives of a child, and no parent, the whole shall descend and be distributed to the next of kin in equal degrees to the deceased ...." N.Y. DECED. EsT. LAw \$ 83. "Next of kin" as employed in this statute includes only blood relations. Matter of Waring, 275 N.Y. 6, 9 N.E.2d 754 (1937).

${ }^{12}$ Comment, 28 IND. L.J. 620, 631 (1953).

In However, this would seem to be unlikely since the child would probably be considered the illegitimate child of the donor, and illegitimate children generally do not take from the father under intestacy laws. See Matter of Vincent, 189 Misc. 489, 71 N.Y.S.2d 165 (Surr. Ct. 1947); N.Y. DECED. EsT. LAW \$ 83 (13).
} 
support. It was indicated that the principles of equitable estoppel could be applied for the same purpose. ${ }^{13}$ Although finding such liability is consistent with the general idea of applying equitable estoppel against one whose voluntary act (in this instance, consent to A.I.D.) is responsible for bringing the child into existence, ${ }^{14}$ there is always the danger that a court may find that an illegitimate A.I.D. child is not entitled to the husband's support.

Where custody of the A.I.D. child is contested in a divorce hearing, courts probably will tend to favor the mother since her husband is not related to the child by blood. ${ }^{15}$ Although the welfare of the child generally controls the determination of custody, the fact that the husband is technically, at least, not a parent will strengthen the mother's claim. ${ }^{16}$

Although there was no discussion of the question in Gursky, the possibility that A.I.D. embodies adultery was considered in Orford v. Orford ${ }^{17}$ where the court, basing its reasoning on a definition of adultery that did not require sexual intercourse for the commission of that act, ${ }^{18}$ stated in dictum that the practice of A.I.D. does involve adultery.

The conclusion reached by the court in Gursky was not inevitable. The Sanitary Code of the City of New York ${ }^{19}$ prescribes that a

\footnotetext{
${ }^{18}$ Gursky v. Gursky, Index No. 3811/1962, Sup. Ct. Kings County, N.Y., Aug. 20, 1963.

14 Comment, supra note 11, at 631 .

${ }^{25}$ Ibid.

10 "In all cases there shall be no prima facie right to the custody of the child in either parent, but the court shall determine solely what is for the best interest of the child, and what will best promote its welfare and happiness, and make award accordingly." N.Y. DoM. REL. LAw § 70; Sandfort v. Sandfort, 278 App. Div. 331, 105 N.Y.S.2d 343 (1951).

If the child is adjudicated illegitimate the mother will generally be entitled to its custody. Commissioner of Pub. Welfare ex rel Stuart v. Chandler, 123 Misc. 201, 204 N.Y.S. 187 (N.Y. City Ct. Spec. Sess. 1922).

1749 Ont. L.R. 15, 58 D.L.R. 251 (1921).

18 "In my judgment, the essence of the offense of adultery consists, not in the moral turpitude of the act of sexual intercourse, but in the voluntary surrender to another person of the reproductive powers or facilities of the guilty person; and any submission of these powers to the service or enjoyment of any person other than the husband or the wife comes within the definition of 'adultery'.... Sexual intercourse is adulterous because in the case of the woman it involves the possibility of introducing into the family of the husband a false strain of blood. Any act on the part of the wife which does that would, therefore, be adulterous." Orford v. Orford, supra note 17, at 22-23, 58 D.L.R. at 258. Accord, Doornbos v. Doornbos, No. $54 \mathrm{~S} 14981$, Super. Ct. Cook County, Ill., Dec. 13, 1954. But see Hoch v. Hoch, Cir. Ct. Cook County, 11l, 1945, Time, Feb. 26, 1945, p. 58; Strnad v. Strnad, 190 Misc. 786, 78 N.Y.S.2d 390 (Sup. Ct. 1948).
}

${ }^{20}$ NEW YORK, N.Y., SANITARY CODE $\$ 112$. 
physician who practices artificial insemination must keep records regarding his activities and also administer tests to both the donor and the mother. The court in Gursky insisted that the existence of such a law does not sanction the practice of artificial insemination. ${ }^{20}$ However, the existence of the code encourages an orderly application of the technique and in so doing indicates at least a tacit approval of the process. Moreover, the court might have found a clear precedent for declaring the legitimacy of the Gursky child in a New York case $\mathrm{e}^{21}$ where an A.I.D. child, to whose conception the husband had consented, was said to be legitimate. ${ }^{22}$

The strongest argument in favor of finding A.I.D. children legitimate is based on the public policy reflected in the evidentiary presumption of legitimacy. If a child is born to a woman during coverture, the law presumes that the offspring is the legitimate clild of the husband. ${ }^{23}$ It is the general rule in New York that except in affiliation proceedings neither parent may bastardize a child born during marriage by testifying to non-access. ${ }^{24}$ In this presumption and attendant rules of evidence the New York court might have found a means for reaching a more desirable result.

The court in Gursky failed to follow the example set by Anonymous $v$. Anonymous ${ }^{25}$ of subordinating technical considerations to concern for the welfare of the child. In Anonymous, an action for separation, the defendant wife, without making a claim of nonaccess or impotency, contended that her husband was not the father of her child. The court found the child to be legitimate and concluded:

${ }^{20}$ Gursky v. Gursky, Index No. 3811/1962, Sup. Ct. Kings County, N.Y., Aug. 20, 1963. Also, a provision in the city code would seem to be a questionable basis on which to interpret New York state domestic relations law.

${ }^{21}$ Strnad v. Strnad, 190 Misc. 786, 78 N.Y.S.2d 390 (Sup. Ct. 1948).

22 "Indeed, logically and realistically, the situation is no different than that pertaining in the case of a child born out of wedlock who by law is made legitimate upon the marriage of the interested parties." Strnad v. Strnad, supra note 21, at 787, 78 N.Y.S.2d at 392 .

${ }^{23}$ McCornuck, Evidence $\$ 309$ (1954). See Matter of Findley, 253 N.Y. 1, 170 N.E. 471 (1930); Barker v. Barker, 172 App. Div, 244, 158 N.Y.S. 413 (1916).

2t Haynes v. Haynes, 43 N.Y.S.2d 315 (Sup. Ct. 1943); Schatkin, Disputed PaternitY Proceedings 142 (3d ed. 1953).

This limitation, known as Lord Mansfield's Rule, was originally stated as follows: "[T]he law of England is clear that a declaration of a father or mother cannot be admitted to bastardize the issue born after marriage. ... [I]t is a rule founded on decency, morality and policy that they shall not be permitted to say after marriagc that they have had no connection and therefore that the offspring is spurious." Good. right v. Moss, 2 Cowp. 591, 592, 594, 98 Eng. Rep. 1257, 1258 (1777).

${ }^{25} 208$ Misc. 633, 143 N.Y.S.2d 221 (Sup. Ct. 1955). 
[it is] the public policy of this State that a wife will not be permitted to bring an action to declare that her husband is not the father of a child born during lawful wedlock without proof of non-access or impotency and will be denied relief even then in the absence of proof that it is for the best interests of the child.26 (Emphasis added.)

Evidence of artificial insemination might have been excluded in Gursky even though the result would have been to deny relief to the complaining party in an annulment proceeding. It is arguable, however, that in a marriage where annulment would normally be in order, the deliberate conception of a child by means of artificial insemination is an action of such an affirmative nature that a later plea for relief by annulment should be denied. ${ }^{2 \pi}$

The presumption of legitimacy and a strict application of the rules of evidence will not solve every problem arising as a result of A.I.D. since these rules apply only to the husband and wife. Neither will the principle of equitable estoppel, which might be applied against a husband, apply to every person who might raise the question of legitimacy. Where parties other than the husband and wife have an interest in the question of legitimacy, as might occur where relatives contest the A.I.D. child's right of inheritance, the altered legal relationships make the doctrine inapplicable. It is difficult to see, however, how such a situation could change the policy considerations.

An examination that penetrates the common law definitions to inspect the social rationale of the terms "adultery," "out of wedlock," and "illegitimate" clearly reveals that the undesirable factors surrounding the common law transgressions are absent where conception is by means of artificial insemination. ${ }^{28}$ The illegitimate child born to a married woman is typically the product of adultery. Where sexual intercourse is involved, adultery and the resulting illegitimate child tend to break down the family unit by alienating the wife's affections and by secretly creating an alien blood line in the husband's family. Neither of these socially undesirable factors

\footnotetext{
20 Id, at 637,143 N.Y.S.2d at 225.

${ }^{27}$ Some courts have held that an annulment proceeding may be barred by the doctrine of laches. Lukaiser v. Lukaiser, 89 N.Y.S.2d 671 (Sup. Ct. 1949); Bentz v. Bentz, 188 Misc. 86, 67 N.Y.S.2d 345 (Sup. Ct. 1947). A statute of limitations has also been held to bar an action for annulment based upon physical infirmity. Kronman v. Kronman, 247 App. Div. 186, 286 N.Y.S. 627 (1936); Deitch v. Deitch, 161 App. Div. 492, 146 N.Y.S. 782 (1914).

28 Comment, supra note 11 , at 624-27.
} 
is present where the child is the product of A.I.D. However, in spite of the fact that society has a positive interest in finding children legitimate, and in spite of the fact that the practice of A.I.D. incorporates none of the evils that the law associates with the conception of offspring who are not the children of their mother's husband, it seems unlikely that courts, bound by a rigid definitional approach, will consistently categorize the A.I.D. child as legitimate.

The unfortunate result in Gursky might be rectified by relatively simple legislation. ${ }^{20}$ Ground rules which have been suggested for the protection of the medical profession ${ }^{30}$ might supply a basis for such legislation. Apparently, however, no such legislation has yet been passed either to legitimate A.I.D. offspring or to forbid the practice altogether. ${ }^{31}$ It would seem advisable to incorporate in any future legislation a requirement of the husband's consent, strict medical supervision, a central system of record keeping to assure that no inbreeding occurs inadvertently, and strict secrecy. The most urgent need is for a provision as simple as the 1948 bill proposed in Virginia:

Children born as the result of artificial insemination shall be considered the same as legitimate children for all purposes, if the husband of the mother consented to the operation. ${ }^{32}$

\footnotetext{
${ }^{29}$ Catholic doctrine strongly opposes artificial insemination. See Kelly, Artificial Insemination: Theological and Natural Law Aspects, 33 U. DET. L.J. 135 (1955); Rice, A.I.D.-An Heir to Controversy, 34 Notre DAME LAw. 510 (1959).

${ }^{30}$ The rules include: "1. Donor must remain unknown to the husband and the wife. 2. All parties must voluntarily enter into the procedure. 3. Physicians must know the couple well-their intellectual capacity, emotional stability, possibility of their marriage being permanent. . . 5. Husband, and not the biologic father, must be listed on the birth certificate. 6. Signed papers should be kept to a minimum or eliminated entirely." Holloway, Artificial Insemination: An Examination of the Legal Aspects, 43 A.B.A.J. 1089, 1090 (1957).

${ }^{31}$ Hager, supra note 3 , at 230.

${ }^{32}$ Va. Sen. No. 199 (1948).
} 